\title{
The Rights of Parents to Maintenance in Bangladesh: An Overview of the Parents Maintenance Act, 2013
}

Sabina Yasmin*

Senior Lecturer Prime University Dhaka, Bangladesh

DOI: $10.36348 /$ SIJLCJ.2019.v02i10.003

| Received: 04.10.2019 | Accepted: 12.10.2019| Published: 29.10.2019

*Corresponding author: Sabina Yasmin

\section{Abstract}

A loving and harmonious family bond between parents and children will bring peace and tranquility not only to the individual but also to a nation. Children are bound to provide for their parents' maintenance in their old age under the AlQuran and Sunnah. Now-a-days children are often neglecting and avoiding maintaining and looking after their parents' need. The Parents Maintenance Act is a beginning of a new step of protection for those unlucky parents who are often ignored by their children. Though there is specific legislation that provides for rights of maintenance to parents but still necessary to amend more specific provisions to reduce the gap between the existing provisions and reality for the betterment of parents. This paper finds out the rights of parents to maintenance under existing laws in Bangladesh. This study also analyzes the reasons behind not providing proper maintenance to parents by their children as well as addressing some recommendations which will be benefited for parents at their old stage.

Keywords: Rights, Parents, Children, Maintenance, Bangladesh.

Copyright @ 2019: This is an open-access article distributed under the terms of the Creative Commons Attribution license which permits unrestricted use, distribution, and reproduction in any medium for non-commercial use (NonCommercial, or CC-BY-NC) provided the original author and source are credited.

\section{INTRODUCTION}

A family that cares and supports each other's rights and obligations. Parents are concern for maintenance and welfare of the children and spent their time, money, property and everything for proper bringing up their children. Parents become old which is the natural process of life. In this period every human being decreased physical strength and deteriorating health conditions [1]. For this reason they are dependent to their children. They should always be reminded to take this filial duty as an important obligation in life. Parents should not be allowed to suffer in their old age, as they faced lot of suffering when they raised their children. They deserve better attention, care and support rather than hardship and impoverishment. In previous time parent when became old got honour and respect as well as they were considered as an important advisor in the family and also to the community. They are looked after and maintained by their children. In our country adult children are considered to be the main source of economic support and security to their parents particularly in their old age. However this scenario has been changed at present time. Now-a-days traditional joint family has broken and children want to lead a life on his own terms and try to escape from the responsibility and feel burden to keep their parents with them. The family pattern is breaking down due to urbanization, migration, self-interest, maladjustment, and economic hardship. As a result they are not willing to maintain their parents. This situation is causing basic problems and unhappiness for the parents in their old age especially for the poor family. However law made provisions to ensure social security of the elderly parents and compel the children to take good care of their parents by enacting a landmark law named Parents Maintenance Act, 2013. Furthermore children are not allowed to send them in old age homes beyond their wishes. This paper tries to highlight the success stories of maintaining the parents by exiting procedure. In addition to this paper focuses the existing provision and practical scenario regarding the maintaining of parents. This paper also finds out the appropriate remedies to improve the legal provisions for the protection of the rights of the parents.

\section{Conceptual framework}

Parents mean the biological or natural parents of the children and children mean efficient sons or daughters of the biological parents. In this paper children include both son and daughter who are responsible to maintain their parents. Old age surpassing the average life span of human being. Although old age cannot be defined exactly, when parents aged 60 years or above are considered as elderly 
then they become weak in physically and financially. It is the moral duty to provide maintenance to parents for every person. The common meaning of maintenance is the act of supporting. Maintenance includes food, clothing, lodging, medical support and also includes other necessary expenses for mental and physical needs. At present the maintenance of parents is not only moral duty but also legal duty of children.

\section{OBJECTIVE}

The general objective of this article is to explore the legal provision of maintaining parents in their old age. The specific objectives as follows:

- To evaluate the existing laws as well as other initiatives regarding maintenance of parents.

- To find out different remedies provided by the government for the maintenance of the parents at old stage of their life.

- To address some suggestions for possible ways of improvement of implementation of legal rights regarding parents in their old age.

\section{METHODOLOGY}

This article is descriptive in nature and mainly focused on both primary and secondary sources. Primary sources include different laws and regulations regarding the maintenance of parents. The secondary data on this regard were collected from books, websites, journal articles and commentary relating to the maintenance of parents. This paper is based on qualitative study for exploring relevant knowledge to fulfill the objectives of this study.

\section{Reasons for not providing the maintenance}

Now-a-days in our country traditional family patterns are broken due to urbanization and industrialization. As a result it creates nuclear family as well as attitudes of self-interest of children reduce the respect and values to the parents in the family and society. For this reason vulnerability of their old age is increasing. They are facing many mental social and medical problems. At present children are living in cities for education and job purpose. For this reason they do not go to villages to see their Parents. They feel lonely and isolated at their old stage. On the other side that are living in urban area children do not have enough time to spent with and take care their parents. As a result loneliness and anxiety are causing for emotional and mental problem. In our social context after retirement they have no incoming source and no fixed income as well as unfit to work for physical weakness. Therefore elder people become dependent on them. However children feel them burden as the living cost is increasing and they are devoting more time to work to earn more money. Modernization has affected our agro-based society and increased the migration from rural to urban and country to country affecting the pull factors and push factors. Another reason is that older parents in Bangladesh are sending their children abroad for study job and even for settlement. Some young and adult children are leaving their older parents behind and settling down either in the urban center of Bangladesh or in over-seas countries [2,3]. So the older people are living separately from their children and grandchildren. They are mostly vulnerable in case of living arrangement, food consumption and possessions on wealth, participation in decision making of the family and social attitude and values [4]. A study reports that about $55 \%$ are living in their own arrangement, slightly more than $25 \%$ with their sons and around $11 \%$ with their daughters [2]. As a result parents are bound to go old home or live in separately.

\section{Legal provisions regarding maintenance for parents}

In order to ensure the rights and dignity of parents the legislature had laid down various enactments. Constitution of the people's republic of Bangladesh ensures the rights of the elder people along with basic necessities. There are some legal provisions regarding maintenance such as:

\section{Rights of the elder people in the Constitution of Bangladesh}

As per Bangladesh constitution, the fundamental responsibility of the state is to ensure basic needs including the right of social security for the person at their old age. This is one of the fundamental principles of state policy which provides in article 15 (d) of Bangladesh Constitution.

\section{Muslim Law}

There is clear and compulsory instruction about the responsibility of every child towards the parents. In many places in the Holy scripture of Islam, the Qur'an and the Hadith of the Prophet (peace be upon him), the issue of child's responsibilities towards mother has been elaborated with utmost importance. Allah has revealed in the Al-Quran:

"And your Lord has ordained that you worship none but Him, and that you be good to [your] parents; should one or both attain to old age in your life, never say to them 'fie' or any word that implies your weariness of them, nor chide them, but [always] speak to them respectfully. And extend to them a wing of humbleness out of compassion, and say: My Lord, bestow your grace upon them, as they raised me and cherished me when I was little. Your Lord knows best what is in your hearts; if you are righteous [He will forgive you your errors]; surely, He is All-forgiving to those who turn to Him again [in true repentance]." (AlQuran. Al-Isra' 17: 23-25. Rahim Muhammad or Bin A and others)[4].

The verse above provides that the duty to one's parents is among the highest decree next to faith to Allah. Therefore, rights and duties due to the parents are next to the rights and duties due to Allah. It serves as a basis of rights of the parents upon the children. Prophet Muhammad (s.a.w.) has also emphasized on the 
children's duty to care and respect their parents. In a hadith narrated from Abu Hurairah, the Prophet said:

"May his nose be rubbed in the dust, may his nose be rubbed in the dust, and may his nose be rubbed in the dust." It was said: 'Who, O Messenger of Allah?' He said: "The one who's parents, one or both of them, reach old age during his lifetime and he does not enter Paradise [5]."

In other instances, the Prophet had warned his followers on the severity of disrespecting or disobeying the parents where it is regarded as one of the major sins next to associating Allah with others in faith. It has been reported that the Prophet:

"Shall I not narrate to you about the worst of the major sins?" They said: 'Of course O Messenger of Allah' He said: "Associating others with Allah and disobeying the parents. (At-Tirmidhi, Abu Eisa Mohammad, Jami' Hadith no. 3019)[6].

The children will be unfortunate and not able to enter the Paradise who has not taken proper care of their parents with kindness and unwavering loyalty. It will be considered as great sin if any children disobey and do impolite behavior with mother. Under Mohammadan Law children are bound to maintain their parents. Under Muslim Law, relating to maintenance of parents by the children are stated that they are bound to maintain their parents only if they are financially sound and the parents who are in need are entitled to get maintenance from their children. However both the son and daughter have equal duty to maintain their parents and their responsibility to maintain the parents is joint and equal. But if one child is poor and the other is in easy circumstances, then the liability to maintain parents lies on the child who is in easy circumstances. If the child is in a position that he/she can only support one of its parents, always the mother gets priority over father.

In an authentic Hadith of the Prophet, Asma' binti Abu Bakr narrated: My mother, while she was a polytheist during the treaty of Quraish, came to me, I asked: O Messenger of Allah! My mother has come to me while she is ill-disposed (to Islam). Should I show her respect? "Yes" He replied: "Show respect to her". (Al-Bukhari, Muhammad bin Ismail, Sahih AlBukhari 1997 Hadith no. 50)[3].

\section{Hindu Law}

Under Hindu law children are bound to maintain their parents which were first provided in personal law statute Hindu Adoption and Maintenance Act, 1956 which imposes an obligation on the children to maintain their parents. According to this act Hindu law recognizes that the obligation of maintenance of aged person on their sons, who are not able to maintain themselves. It was not only the duty of son to take care their parents, daughter has the same obligation. This Act is a part of Hindu personal laws; there is some limited scope with respect to the maintenance. (Aishwarya D and Prithwish C, Indian journal of research vol.4). According to Section 20 of this Act it is the obligation of children to maintain their aged infirm parents (children here include legitimate as well as illegitimate). The liability to maintain parents is personal and is not dependent on the possession of property and this obligation ceases with the death of the person liable to maintain.

\section{The Family Courts Ordinance, 1985:[7]}

There was no specific legal framework to bring any legal action against the children for ensuring maintenance of the parents before this Act. However, they could file law suit under section 5(d) of the Family Courts Ordinance 1985 for maintenance. It was observed in the case of Jamila Khatun $v$ Rostom Ali reported in 48 DLR (AD) 110 that "under Mohammedan Law children in easy circumstances are bound to maintain their poor parents, although the later may be able to earn something for themselves. These poor parents may also file a suit in the Family Court for maintenance from their opulent children under the Ordinance of 1985.If any children do not maintain these then parents can file a suit for maintenance under family court ordinance, 1985. Unfortunately the suit under this ordinance by parents is not wide practice as the provisions are not enclosed specifically. However most of the parents do not know about this provision.

\section{Parents Maintenance Act, 2013 [8]}

The government of Bangladesh has enacted a law in this regard named Pita Mata Voron Poson Ain 2013 to bring legal action for ensuring the maintenance by their children. This law deals with the maintenance of the parents which envisages that every child shall ensure the maintenance of his or her parents and if there is more than one child alive to the parents, they have to consult each other and shall ensure the maintenance of his or her parents. The provision also imposes upon the children to live with their parents. In so doing, the children shall secure the medical care and attendance of their parents. This is a common phenomenon in our society that the offspring leave their aged parents in a miserable condition. In order to prevent this unacceptable practice, provisions have been incorporated in this section which lies down that the children shall never compel their parents to live at any other place against their will. The Act also provides penalty for not providing parents with maintenance which says that if any child violate he shall be liable to pay a fine up to one lakh taka, failing to pay which makes him liable to suffer imprisonment up to three months. The section further provides that if the spouse of any children or grandchildren or any other relative hampers and induce the children not to provide maintenance to the parents they shall be liable for the same punishment which is one of the unique features of 
the Act. However this act also includes the provisions regarding the process of arbitration and mediation and provides the scope for the complaint to be disposed of by compromise between the parties. The Court may send the complaint to the local government representatives, e.g., concerned Chairman, Member of Union Council or Mayor, Counselor of City Corporation or to any competent person to resolve the complaint by compromising and if they can arrive at any decision it shall be deemed to the competent Court. This Act may be treated as the landmark in case of ensuring the sacred duty by the children to maintain their parents. Because there are some remarkable decision might have been come from the court after passing this Act which creates an example of how legal mechanism can really protect the rights of elderly parents. The first case has been filed by the Rangamati Unit of Bangladesh Legal Aid and Services Trust (BLAST) to the Chief Judicial Magistrate Court under the Rangamati District on behalf of a justice seeker. The judgment was in the favour of applicant.

\section{Pitfalls of the Existing laws}

The government of Bangladesh has enacted the law Parents Maintenance Act, 2013 to ensure the maintenance of parents by their children. Before enacting that a lawsuit was filed for maintenance under the family court ordinance 1985 against their issues has not been noticed in wide practice. Though this act have some positive aspect after passing, there are number of cases have been filed but there are some loopholes and limitation of this act. The Government is yet to pay its attention to improve the law and facilitate its proper implementation. However under this act father and mother mean biological ones does not include the step parents and this is not clear that whether the step mother or father are entitled to get maintenance by their step children. The Act states about aged parent and grandparents who have children or grandchildren but didn't say anything who have no children. There should be specification. The Act provides each of the children will have to pay a reasonable amount from their earning if the parents do not live with the children. As a result there remains ambiguity as to determination of the amount for maintenance. Like the Indian court, our court has the discretionary power to determine the minimum and maximum amount of maintenance considering the circumstanc. However it cannot make any order for monthly allowance under this Act. Another limitation of this act, only the aggrieved parent is entitled to bring complaints. Sometimes the parents might be illiterate or not may be in a position to file such complaint. Therefore the provision should be amended to enable such complain on behalf of parents. However another loophole there is no specific time limitation to solve the cases for speedy justice and effective decision making under this Act. There is no provision of order of interim maintenance for the parents during the pendency of the suit as well as the court are not enabling to provide money to the victim from the accused as penalty under this Act. Another defect of the Act is that cognizance of Court under the Act has been made conditional in section 7 which stipulates that no Court shall take cognizance of offence under the Act except upon a complaint filed by the parents or upon a complaint written by the parents, but different situations may arise where parents might be illiterate or may not be in a position to file complaint themselves or the parents may be unduly influenced or emotionally blackmailed by their children or may be reluctant to file a complaint against the children on any other ground.

There is an obligation on the children that they can't compel their parents to live in the old home or separately. But there is no indication that if the parents are willing to live separately but the children are unable to main double residential cost. Though the Act deals with the rulemaking power of the government to frame rules for the purpose of fulfilling the object of the Act but no rules have yet been framed. Despite having some lacunas in the Act, we should appreciate the government for enacting such type of remedial and beneficial statute, which will be a basis for securing the maintenance of their parents. Another drawback of this act thatIt does not provide for the maintenance of adoptive or childless parents. Though the Act has established the parents' legal entitlement to maintenance from child, it is silent as to whether they are entitled to bring civil suit for maintenance in the Family Court. It does not also clarify whether the parents would get fine or money.

\section{RECOMMENDATIONS}

The Parent's Maintenance Act seems to be adopted to ensure legal action for the parents in reality and needs to be amended to serve the intended purpose.

- The suit by the parents for maintaining them should be cost effective and speedy trial. The provisions of summary trials should be introduced by the tribunals for passing orders for maintenance for parents.

- Alternative dispute resolution should be introduced in this act because subject matter is family matter in nature and parents should get their remedy quickly and without spending money. The court before hearing an application may, refer the same to a conciliation officer and he shall submit his findings with limited time and if amicable settlement has been arrived at the court shall pass an order to that effect.

- There should have a provision for camera trial under this Act because open trial of this type of issue can hamper both parties social status.

- Pita Matar Voron Poson Ain should be amended to provide monthly allowance as an interim maintenance of parents during the pendency of suit.

- The awareness program for motivation to the children for care and responsibility of their parents should be initiated. The government and media can 
arrange different program including the successful judgment under the Act.

- The Government shall take all measures to ensure the provisions of this Act are given wide publicity through public media including the television, radio and the print at regular intervals;

- The police officers and the members of the judicial service are arranging awareness training on the issues relating to this Act;

- Effective co-ordination between the services provided by the concerned Ministries or Departments dealing with law, home affairs, health and welfare, to address the issues relating to the welfare and maintenance of the respected parents are needed and periodical review of the same is conducted.

- The government will make a policy based on which it will establish Parents Care Centers to ensure their maintenance and certify any institution which may be private to be parents care center with a gazette notification .Moreover this center should be considered as the last option if children are unable to maintain them.

- The Government should be pay attention to modify the existing laws and remove its loopholes by facilitating its proper implementation in practice.

- The non-government organization and others should come forward to take care and give mental and financial support for the security of the respected parents.

\section{CONCLUSION}

Parents in their old stage face the problem of financial and nursing support and they are neglected by their own family members. They may not be maintained due to lack of economic solvency of the society and forming nuclear family [9]. Many other countries in the world enacted specific provisions for ensuring the rights of maintenance of parents. Singapore and India are among the pioneers in legislating specific laws to enforce children's obligation to specifically maintain the parents and ensure all kinds of welfare of them. Though Bangladesh enacted the Parents Maintenance Act, 2013 which have some positive provisions for securing the maintenance of parents at their old stage and make their children accountable if they deny their responsibility, it has some loopholes. Each family member especially children should come forward to give mental and financial support instead of neglecting them. The Government should take appropriate step to implement the existing laws and by incorporating the lacunas of this act. In addition to this other nongovernment organization as well as private organization can also take some measures for the well-being of our respected parents. Though the government has drafted the Parents' Maintenance Rules, 2017 to give full effect to the Act but it is yet not to be finalized. The government would take necessary initiatives to recap the contemplated purposes of this act and enact social welfare oriented law.

\section{REFERENCES}

1. Barikder A.A. T., \& Lasker, P.S. (2016). The Situation of the Elderly In Bangladesh, Bangladesh Journal of Bioethics.

Francine Rossuo, Caring for Aging Parents: Should There Be a Law?,[http://healthland.time.com/2013 /07/22/caring-for-aging-parents-should-there-be-alaw/, 2014

2. Rahman, H., (1999) International year of the older persons and the cases of Bangladesh. Bangladesh Journal of Geriatrics, 36: 144-144

3. Al-Bukhari, Muhammad bin Ismail, Sahih AlBukhari (Translation by Dr. Muhammad Muhsin Khan) (1997). Riyadh, Maktaba Dar-us-Salam, The Book of Gifts, Chapter 29, Hadith no. 2620. See also Muslim, Ibid. Book of Zakat, v.3, Hadith no. 50.

4. Al-Quran. Al-Isra' 17: 23-25.

5. Muslim, A. (2007). The Book of Virtue, Enjoining Good Manners and Joining of the Ties of Kinship. In Sahih Muslim. Riyadh: Darussalam, Hadith, 6(9)

6. At-Tirmidhi, Abu Eisa Mohammad, Jami' AtTirmidhi (Translation by Abu Khaliyl).(2007). Riyadh, Maktaba Dar-us-Salam, Book on the Tafsir of Quran, Chapter 4, Hadith no. 3019.

7. The Family Court Ordinance, (1985).

8. Ayin Kurratu. (2017). An Overview of the Parents Maintenance Act2013 in Bangladesh: Limitation \& Encumbrance. An Article of Academia. Edu.

9. Islam, N. M., \& Nath, C.D. (2012). AFuture Journey to the Elderly Support in Bangladesh, A Reasearch Article Journal of Antrhopology Hinduar Publication Corporation.

\section{Enacted Laws}

The Constitution of the People's Republic of Bangladesh 1972

Parents Maintenance Act, 2013, Act no 49 of Bangladesh

The Hindu Adoption and Maintenance Act, 1956 